\title{
AO SEPTUAGÉSIMO ANIVERSÁRIO DO PROFESSOR DOUTOR JAN KLÍMA (2013)
}

Em dezembro vai celebrar o seu $70^{\circ}$ aniversário o Professor Doutor Jan Klíma, que nasceu a 8 de dezembro de 1943, em Vysoké Mýto. O Professor Klíma é um especialista na história dos países de língua portuguesa, quer em África, quer na América ou na Ásia, e na questão dos impérios coloniais.

Vamos agora apresentar a vida deste professor universitário, historiador e poliglota que fala Inglês, Português, Espanhol, Alemão e alguns dialetos indígenas utilizados nas antigas colónias portuguesas.

Jan Klíma frequentou o ensino primário e secundário na sua cidade natal (graduou-se em 1960, após onze anos de escola). Depois de frequentar o Instituto Pedagógico em Pardubice (1960-1964), graduou-se pela Faculdade de Artes da Universidade Carolina de Praga (1967-1972). Em 1973 doutorou-se em história geral. Entre 1974 e 1976, completou os seus estudos de pós-graduação na Faculdade de Artes da Universidade Carolina.

A sua carreira pedagógica começou nas escolas secundárias de Tatenice e Luže. Continuou a ensinar no colégio da sua cidade natal (1972-1990), do qual mais tarde se tornou diretor (1990-1992). Jan Klíma vive até hoje com a sua esposa Marcela em Vysoké Mýto, com quem tem dois filhos, Tomáš e Jan, um neto e duas netas. Entre 1985 e 1988, trabalhou como especialista do comércio externo na Polytechna em Moçambique. Em 1992, tornou-se membro do corpo diplomático checo na capital angolana Luanda. A sua missão diplomática terminou com as evacuações devidas ao reinício da guerra civil, já que a embaixada checa se localizava entre as sedes das duas partes em conflito.

A partir de 1993, Klíma trabalhou na Universidade de Hradec Králové como professor de história. Contribuiu significativamente para o crescente interesse no estudo da cultura lusófona e da história e do presente dos países de língua portuguesa. Em 2000, formou-se no campo da história geral. Posteriormente, estabeleceu o Gabinete de Estudos Iberoamericanos e dedicou-se à história dos países de língua portugesa em África, na Europa e na América, participando ainda em várias conferências científicas e profissionais e colaborando com revistas profissionais nacionais e estrangeiras. Os seus esforços resultaram na criação do Departamento de Ciência Política da Faculdade de Filosofia da Universidade de Hradec Králové, que incide especialmente ao estudo de África e da América Latina.

Em 1998, o Professor Jan Klíma participou na expedição Monoxylon II, em que foram testadas hipóteses pré-históricas de navegação, utilizando métodos e técnicas 
de arqueologia experimental. ${ }^{1}$ Participou também com o geólogo Jan Vítek numa expedição a Cabo Verde em 2002, que levou à aquisição de material geológico e de valiosos documentos históricos sobre os Falcões de Cabo Verde. Os esforços iniciados nesta expedição foram concluídos em 2015, com a afixação de uma placa comemorativa em Mindelo, na ilha de São Vicente, que recorda as atividades da organização Falcões de Cabo Verde, que operou nas ilhas entre 1932 e 1939, seguindo o exemplo dos Falcões Checos. A partir desta experiência, Jan Klíma publicou uma monografia bilingue sobre o movimento dosFalcões de Cabo Verde.

Quando não se dedica ao trabalho ou aos estudos, Klíma gosta de relaxar com a música no papel de pianista swing. O professor é conhecido como músico, compositor e maestro. Desde 1971, fundou várias bandas e participou em produções teatrais como autor ou encenador.

Klíma dedicou e ainda dedica uma grande parte da sua energia à publicação. O número dos seus artigos, estudos, avaliações especializadas e contribuições científicas para coleções ultrapassa a centena. O número dos seus livros publicados é superior a trinta. Uma grande parte desses títulos (história de Portugal, Brasil, Angola, Moçambique, Namíbia) foi a primeira história destes países escrita em checo. Temos de mencionar a história dos países e territórios quase desconhecidos no nosso país, como a Guiné-Bissau, Macau, Timor Leste e a Índia Portuguesa. O conhecimento íntimo de cultura, língua e história portuguesas tornou possível passar aos leitores checos factos sobre figuras importantes da história portuguesa, mas também mundiais, tais como António de Oliveira Salazar e Vasco da Gama.

O seu coração está enraizado em Cabo Verde. Klíma escreveu sobre o desenvolvimento cabo-verdiano em geral e complementou-o com um diário de viagem. Graças aos contactos pessoais e ao trabalho do campo escreveu também um estudo sobre os Falcões de Cabo Verde, a única "pegada checa" deles em África. Além de África, de cuja história apresentou numa extensa síntese, Jan Klíma também se interessou pela América Latina, de cujo desenvolvimento deu uma visão geral, mas escreveu também livros que abordam os esforços dos mais importantes "antecessores" e vencedores da luta de libertação nos séculos XVIII e XIX. Klíma é ainda autor de numerosos artigos e textos populares em revistas (a Ibero-Americana Pragensia, o Journal of Ibero-American Studies, a Historický obzor, a Dějiny a současnost, a Archivní časopis, a Mezinárodní vztahy e a Mezinárodní politika, entre outras), para além de contribuições para antologias e comentários. Além das palestras na sua Alma Mater, Klíma desloca-se muitas vezes a outras universidades checas e estrangeiras. É uma alegria ouvir uma das suas palestras e conversar com ele sobre países distantes, porque Klíma não é apenas um excelente professor, mas também, acima de tudo, um homem.

Como é evidente a partir da breve análise acima, a vida pessoal e profissional de Jan Klíma é ainda hoje muito rica e multifacetada. No seu aniversário, desejamos-lhe

1 Os participantes da expedição sob a liderança do Professor Radek Tichý da Universidade de Hradec Králové criaram o barco monoxyl com a ajuda de ferramentas primitivas, a partir do conhecimento documentado do período neolítico. No barco, a expedição seguiu os passos dos marinheiros neolíticos pela parte sul da costa da Europa, terminando em Lisboa, onde foi o único representante da República Checa na Expo 1998. 
sinceramente que permaneça saudável e cheio de energia e que continue a encontrar a satisfação em todas as suas atividades científicas, educacionais e artísticas bem como nas suas viagens para que possa transmitir a sua experiência e sabedoria a todos os seus alunos.

\author{
por Alena Rudolfová (Praga) \\ (Escrito en portugués por la autora)
}

Apresentaremos agora algumas das inúmeras publicações científicas de Jan Klíma:

\title{
MONOGRAFIAS
}

Angola. 2003. Praha: Libri (Stručná historie států) Brazílie. 2003. Praha: Libri (Stručná historie států)

Dějiny Afriky. Vývoj kontinentu, regionů a států. 2012. Praha: Nakladatelství Lidové noviny

Dějiny Angoly. 2008. Praha: Nakladatelství Lidové noviny

Dějiny Brazílie. 1998 (1. ed.), 2011 (2. ed.). Praha: Nakladatelství Lidové noviny

Dějiny Guineje-Bissau. 2015. Praha: Nakladatelství Lidové noviny

Dějiny Kapverd, Svatého Tomáše a Princova ostrova. 2014. Praha: Nakladatelství Lidové noviny

Déjiny Latinské Ameriky. Vývoj oblasti, regionů a států. 2015. Praha: Nakladatelství Lidové noviny

Dějiny Mosambiku. 2010. Praha: Nakladatelství Lidové noviny

Dějiny Namibie. 2015. Praha: Nakladatelství Lidové noviny

Dějiny Portugalska. 1996 (1. ed.), 2007 (2. ed.). Praha: Nakladatelství Lidové noviny

Dějiny Portugalska v datech. 2007. Praha: Libri

Dekolonizace portugalské koloniální říše. Historická motivace, specifika, průběh. 2000. Hradec Králové: Gaudeamus

Guinea-Bissau. 2006. Praha: Libri (Stručná historie států)

Kapverdské ostrovy. Historie a georeliéf. 2003. Hradec Králové: Gaudeamus (con Jan Vítek)

Kapverdské ostrovy. Svatý Tomáš a Princův ostrov. 2008. Praha: Libri (Stručná historie států)

Kapverdští Sokolové. Česká inspirace v dějinách atlantského souostroví. 2016. Ústí nad Orlicí: Oftis

Macao. 2012. Praha: Libri (Stručná historie států)

Madeira. 2011. Praha: Libri (Stručná historie států)

Mosambik. 2007. Praha: Libri (Stručná historie států)

Namibie. 2009. Praha: Libri (Stručná historie států)

Pod německou vlajkou. Příběh jedné koloniální ř̌iše. 2005. Praha: Libri

Portugalská Indie. 2010. Praha: Libri (Stručná historie států)

Poslední koloniální válka. 2001. Praha: Libri,

Předchůdci latinskoamerické svobody. Tiradentes - Hidalgo - Artigas. 2016. Praha: Scriptorium

Salazar, tichý diktátor. 2005. Praha: Aleš Skřivan ml.

Simón Bolívar. 1983. Praha: Panorama

Simón Bolívar. 1988. Katowice: Ślask

Studie z dějin Portugalska a portugalského zámoří. 1999. Hradec Králové: Gaudeamus

Východní Timor. 2003. Praha: Libri (Stručná historie států)

Zámořské objevy. Vasco da Gama a jeho svět. 2006. Praha: Libri

Zrození Latinské Ameriky. Simón Bolívar a jeho doba. 2007. Praha: Libri

\section{Livros de viagens}

Kam dohlédnu z Vumby (cesty po Mosambiku a Zimbabwe). 1990. Praha: Panorama

Kapverdy znovu objevené. 2002. Hradec Králové: Paradise Studio (con Jan Vítek) 